\title{
Two Mutations in the Hormone Binding Domain of the Vitamin D Receptor Cause Tissue Resistance to 1,25 Dihydroxyvitamin $D_{3}$
}

\author{
Kristleifur Kristjansson, * Andrew R. Rut, ${ }^{*}$ Martin Hewison, ${ }^{\ddagger}$ J. L. H. O’Riordan, ${ }^{\star}$ and Mark R. Hughes * \\ ${ }^{*}$ Institute for Molecular Genetics, Baylor College of Medicine, Houston, Texas 77030; and ${ }^{\ddagger}$ Department of Medicine, \\ The Middlesex Hospital, London WIN 8AA, United Kingdom
}

\begin{abstract}
We have identified and characterized two mutations in the hormone binding domain of the vitamin D receptor (VDR) in patients with hereditary vitamin D-resistant rickets. One patient was found to have a premature stop mutation (CAG to TAG) in the hinge region affecting amino acid 149 (Q149X) and the other demonstrated a missense mutation (CGC to CTC) resulting in the substitution of arginine 271 by leucine (R27IL) in the steroid binding domain. Eukaryotic expression analyses in CV1 cells showed the inability of both patients' VDR to induce transcription from the osteocalcin hormone gene response element at $10^{-7} \mathrm{M} 1,25$-dihydroxyvitamin $\mathrm{D}_{3}\left(1,25(\mathrm{OH})_{2} \mathrm{D}_{3}\right)$. Normal transcription levels could, however, be elicted by the missense mutated VDR (R271L) in the presence of 1,000-fold higher 1,25- $(\mathrm{OH})_{2} \mathrm{D}_{3}$ concentrations than needed for the wildtype receptor. This shows that Arg 271 directly affects the affinity of the VDR for its ligand and its conversion to leucine decreases its affinity for $1,25(\mathrm{OH})_{2} \mathrm{D}_{3}$ by a factor of 1,000 . Arg 271 is located immediately 3-prime to a 30 amino acid segment (VDR amino acids 241-270) that is conserved among members of the steroid/thyroid/retinoid hormone receptor superfamily. These results represent the first missense mutation identified in the hormone binding domain of VDR and further define the structure-function relationship of $1,25(\mathrm{OH})_{2} \mathrm{D}_{3}$ ligand binding to its nuclear receptor. (J. Clin. Invest. 1993. 92:12-16.) Key words: rickets • calcitrol • steroid • genetic • transcription-genetic
\end{abstract}

\section{Introduction}

The biological effects of 1,25-dihydroxyvitamin $D_{3}(1,25$ $\left.(\mathrm{OH})_{2} \mathrm{D}_{3}\right),{ }^{1}$ the hormonal form of vitamin $\mathrm{D}$, are mediated by its binding to a specific intracellular receptor present in target cells (1-3). The $48-\mathrm{kD}$ receptor belongs to the family of steroid/thyroid/retinoid nuclear hormone receptors (4). These

This work has been reported in abstract form (1992. Am. J. Hum. Genet. 51:A131).

Address correspondence to Dr. Mark Hughes, Room T917, Institute for Molecular Genetics, Baylor College of Medicine, One Baylor Plaza, Houston, TX 77031.

Received for publication 14 December 1992 and in revised form 18 February 1993.

1. Abbreviations used in this paper: CAT, chloramphenicol acetyltransferase; HVDRR, hereditary vitamin D-resistant rickets; $1,25(\mathrm{OH})_{2} \mathrm{D}_{3}, 1,25$-dihydroxyvitamin $\mathrm{D}_{3}$; VDR, vitamin $\mathrm{D}$ receptor.

J. Clin. Invest.

(c) The American Society for Clinical Investigation, Inc. 0021-9738/93/07/0012/05 \$2.00

Volume 92, July 1993, 12-16 receptors act in trans by binding to specific cis-acting DNA sequences in the promotor regions of hormone-responsive genes, thereby modulating their transcription (5). Receptors belonging to this superfamily comprise two functional domains: a ligand binding and a DNA binding domain (4). The DNA binding domains show high evolutionary conservation in a region of 60-70 residues that form two zinc fingers essential for interaction with DNA $(4,6-10)$. The high amino acid homology within this region predicts a three-dimensional organization common to the individual members of the gene family. The interaction of the glucocorticoid receptor DNA binding domain with its DNA hormone response element has recently been resolved by crystallographic analysis (11), and on this basis we have analyzed the stereochemical consequences of vitamin $\mathrm{D}$ receptor (VDR) mutations identified in patients with tissue resistance to $1,25(\mathrm{OH})_{2} \mathrm{D}_{3}(12)$.

Structure-function relationships of the hormone binding domain are much less well understood. The potential importance of individual amino acids in this domain is inferred by their evolutionary conservation throughout the receptor superfamily (4). For example, subdomains within the carboxy-terminal half of these receptors that affect ligand binding, receptor dimerization, and transcriptional activation have been identified $(9,13-17)$. Further insight has been obtained from mutations intentionally created in this domain, together with reports of receptor mutations in patients with tissue resistance to the various steroid hormones $(9,13,15,18-26)$. Only one of the published mutations in the human VDR has been in the hormone binding domain (25). Here we report the identification and characterization of two mutations located in the hormone binding domain of this receptor from patients with classical features of hereditary vitamin D-resistant rickets (HVDRR).

\section{Methods}

Patients. The patients presented in early childhood with classical features of tissue resistance to $1,25(\mathrm{OH})_{2} \mathrm{D}_{3}$, including severe bowing of weight-bearing bones (rickets), and one patient had alopecia. They both had elevated parathyroid hormone and very high levels of serum $1,25(\mathrm{OH})_{2} \mathrm{D}_{3}$. The patients were unrelated but both were of Middle Eastern origin and their parents were consanguineous. Neither showed any clinical improvement by high dose $1,25(\mathrm{OH})_{2} \mathrm{D}_{3}$ therapy (up to 50 $\mu \mathrm{g} / \mathrm{d})$. Biochemical evaluation was consistent in both patients with HVDRR. Detailed case histories have previously been published and receptor binding data showed no detectable cytoplasmic or nuclear $1,25(\mathrm{OH})_{2}\left[{ }^{3} \mathrm{H}\right] \mathrm{D}_{3}$ association $(27,28) .25$-Hydroxyvitamin-D-24-hydroxylase induction was measured in skin fibroblasts obtained by biopsies from patients and normal individuals. The conversion of 25-hydroxyvitamin- $\left[{ }^{3} \mathrm{H}\right] \mathrm{D}$ to 24,25 -dihydroxyvitamin- $\left[{ }^{3} \mathrm{H}\right] \mathrm{D}$ by the 24 -hydroxylase was determined as described (29) and plotted against the elution profile for a mixture of standard vitamin $D$ metabolites. The production of radiolabeled 24,25-dihydroxyvitamin $D_{3}$ was expressed as femtomoles per hour per $10^{6}$ cells. 
RNA isolation, cDNA synthesis, and PCR amplification. Total RNA was isolated from patient skin fibroblast cultures by standard protocols (RNAzol B; Cinna/Biotex Laboratories, Houston, TX). First strand cDNA synthesis was performed with Superscript RNase H-reverse transcriptase (Bethesda Research Laboratories, Gaithersberg, MD), $10 \mu \mathrm{g}$ total RNA, and a VDR primer specific to the early $3^{\prime}$ untranslated sequence (primer 31b: 5'-GCCCTGGAGGAGCAGCCC, $0.8 \mathrm{M}$ final concentration; Fig. 1). The reaction was incubated at $45^{\circ} \mathrm{C}$ for $60 \mathrm{~min}$ in a total volume of $40 \mu$ l. The full-length VDR coding region was amplified by PCR (30) using primers 31a (5'-GAGCACCCCTGGGCTCCA ) and $31 \mathrm{~b}(0.16 \mu \mathrm{M}$ final concentration) (Fig. 1) and $2 \mu$ of the reverse transcription reaction as template (standard buffer conditions of Perkin Elmer-Cetus, Norwalk, CT, and $2.0 \mathrm{mM} \mathrm{MgCl}_{2}$ with 35 cycles of $90^{\circ} \mathrm{C}$ for $1 \mathrm{~min}, 50^{\circ} \mathrm{C}$ for $1 \mathrm{~min}$ and 20 $\mathrm{s}$, and $72^{\circ} \mathrm{C}$ for $6 \mathrm{~min}$ ). To facilitate complete sequencing, each half of the coding region was amplified by a nested PCR reaction, using primers 32a (5'-CCTGCCCCTGCTCCTTC) and 32b(5'-AGGTCAGCCAGGTGGGGC) for the $5^{\prime}$ half and 33 a ( $5^{\prime}$-CCCAGCTCTCCATGCTGC) and 33b (5'-CCCAGGCACCGCACAGGC) for the $3^{\prime}$ half $\left(0.16 \mu \mathrm{M}\right.$ primer concentration at 2.5 and $1.5 \mathrm{mM} \mathrm{MgCl}_{2}$, respectively, for 35 cycles at $95^{\circ} \mathrm{C}$ for $1 \mathrm{~min}$ and $20 \mathrm{~s}$ and $72^{\circ} \mathrm{C}$ for $1 \mathrm{~min}$ and $40 \mathrm{~s}$, with $4 \mathrm{~s}$ extension per cycle; Fig. 1 ).

Cloning and sequencing of amplified DNA. The PCR products were cloned into Bluescript II pSK- plasmid (Stratagene, La Jolla, CA). Positive clones were sequenced by the dideoxy chain termination method using fluorescence labeled M13 reverse primer on an automated sequencer (Applied Biosystems, Inc., Foster City, CA). The full-length VDR coding region was subcloned in a sense orientation into the EcoR 1 and Xbal sites of the expression vector pSVK3 (Pharmacia, LKB Biotechnology Inc., Piscataway, NJ) (31). For exclusion of Taq polymerase and sequencing errors, all steps were performed in duplicate, starting with the reverse transcriptase reaction, and several clones of each PCR product were sequenced in both orientations.

Reporter construct. A 881-bp 5'-untranslated fragment of the human osteocalcin gene including the VDR hormone response element (32) was amplified by PCR from human genomic DNA using the following primers: 5'-CTGCAGGGTCAGGAGGAGAATCG and 5'GTCGCGTCGGTGGGCTCT. Reaction conditions included standard Cetus buffer, $2.0 \mathrm{mM} \mathrm{MgCl}$, and $0.2 \mu \mathrm{M}$ primer concentration for 35 cycles of $95^{\circ} \mathrm{C}$ for $1 \mathrm{~min}, 58^{\circ} \mathrm{C}$ for $1 \mathrm{~min}$, and $72^{\circ} \mathrm{C}$ for $2 \mathrm{~min}$. The PCR product was cloned into the reporter plasmid pCAT Basic (Promega Corp., Madison, WI), thereby fusing the osteocalcin gene promoter/enhancer region upstream of the chloramphenicol acetyltransferase (CAT) gene.

$V D R$ cotransfection assay in $C V-1$ cells. VDR-deficient $C V-1$ cells were grown in DME supplemented with $10 \%$ FCS and L-glutamine (2 $\mathrm{mM}) .24 \mathrm{~h}$ before transfection the cells were plated to a density of 1 $\times 10^{6}$ cells $/ 10-\mathrm{cm}$ plate. Transfection was carried out by the polybrene method as described (7) using $1 \mu \mathrm{g}$ of expression plasmid together with $5 \mu \mathrm{g}$ of human osteocalcin reporter plasmid. After a $30-\mathrm{s}$ glycerol shock, cells were cultured in DME-Nutridoma (Boehringer Mannheim Corp., Indianapolis, IN) supplemented with the desired concentrations of $1,25(\mathrm{OH})_{2} \mathrm{D}_{3}$ in ethanol (final concentration $0.1 \%$ ). Cells were washed with PBS and harvested by scraping $72 \mathrm{~h}$ later, subjected to three freeze-thaw cycles $\left(37^{\circ} \mathrm{C} /-135^{\circ} \mathrm{C}\right)$ in $0.25 \mathrm{M}$ Tris- $\mathrm{HCl}, \mathrm{pH} 7.8$, and centrifuged, and the supernatant $(20 \mu \mathrm{g}$ protein $)$ was assayed for CAT activity $\left(37^{\circ} \mathrm{C}\right.$ overnight) (33). Products were resolved by thin layer chromatography and after autoradiography the relevant portions were excised and quantitated by liquid scintillation counting. The results are expressed as percentage CAT conversion and represent the average of three separate transfection experiments.

\section{Results}

Initial assessment of VDR bioactivity in fibroblasts of these patients was determined by $1,25(\mathrm{OH})_{2} \mathrm{D}_{3}$-mediated induction of the 25-hydroxyvitamin-D-24-hydroxylase (34). Cells from both patients failed to show any significant induction of 24-hydroxylase activity when cultures were exposed to $1,25(\mathrm{OH})_{2} \mathrm{D}_{3}$ at concentrations as high as $1 \mu \mathrm{M}$ (results not shown). This contrasts with normal control fibroblasts that produced $489 \pm$ $119 \mathrm{fmol} / \mathrm{h}$ per $10^{6}$ cells of 24,25-dihydroxyvitamin $D_{3}$ at 10 $\mathrm{nM} 1,25(\mathrm{OH})_{2} \mathrm{D}_{3}$ and is in agreement with the lack of response to vitamin $\mathrm{D}_{3}$ therapy in these patients.

Mutational analysis. A different nucleotide point mutation was identified in each patient. One was found to have $\mathrm{C} \rightarrow \mathrm{T}$ transition at codon 149 (CAG to TAG; Fig. 2), replacing the normal glutamine codon with a termination codon and resulting in a truncated receptor missing 303 residues of the hormone binding domain. The other patient demonstrated a substitution of a $\mathrm{G}$ for a $\mathrm{T}$ in codon 271 , resulting in a missense mutation (CGC to CTC), with exchange of a basic hydrophobic arginine for a nonpolar, hydrophobic leucine (Fig. 2). In both patients and in four others (unpublished results) we identified a single initiation codon (ATG) at nucleotide position 125 , counting from the beginning of the published sequence (GenBank\# J03258) (7). This is different from the originally reported sequence in which two putative transcription initiation sites (at 116 and $125 \mathrm{bp}$ ) were found (7). The former of these was absent in all of our patients, consistent with the findings of Saijo et al. (35). This could represent a polymorphism in the population resulting in two different receptor species that differ in length by 3 amino acids at the amino terminus. Our numbering of amino acids and their codons is from the single initiation site at position 125 .

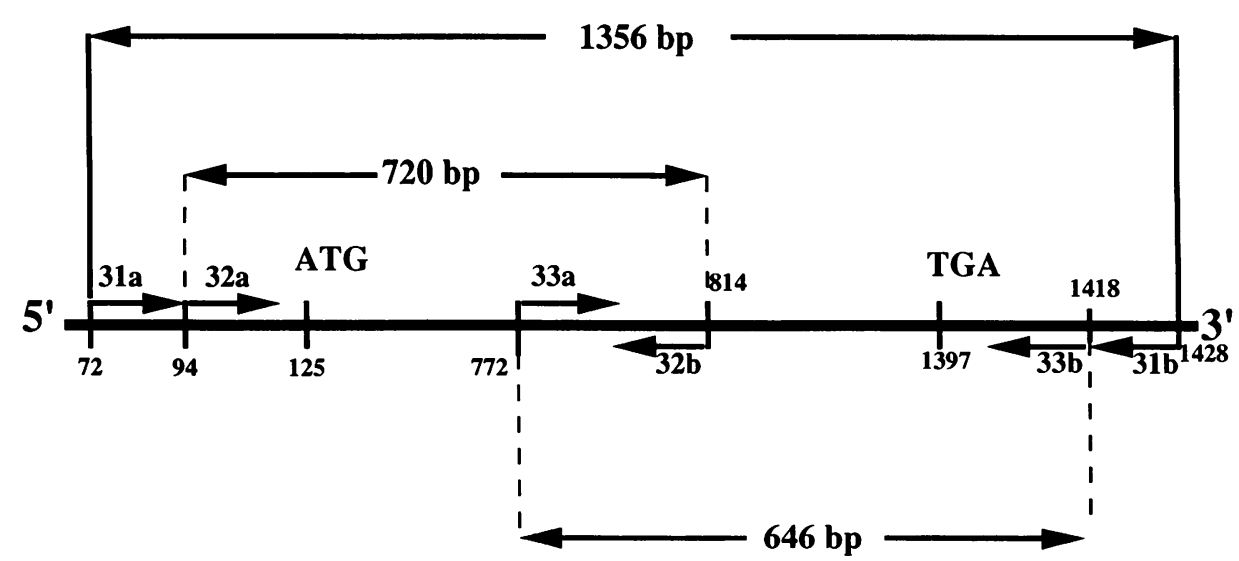

Figure 1. Reverse transcription and PCR amplification of the hVDR cDNA. cDNA was made from total RNA using primer $31 \mathrm{~b}$. The full-length coding region was amplified from the first strand CDNA by PCR using primers $31 \mathrm{a}$ and $31 \mathrm{~b}$. Each half of the gene was subsequently amplified by nested PCRs using primers $33 \mathrm{a}$ and $33 \mathrm{~b}$ for the $3^{\prime}$ half and $32 \mathrm{a}$ and $32 \mathrm{~b}$ for the 5 ' half, giving rise to 646- and 720-bp fragments, respectively. The PCR products were then gel purified, cloned, and sequenced. Basepair numbering refers to the location of the primer ends with respect to the cDNA sequence as originally published. 


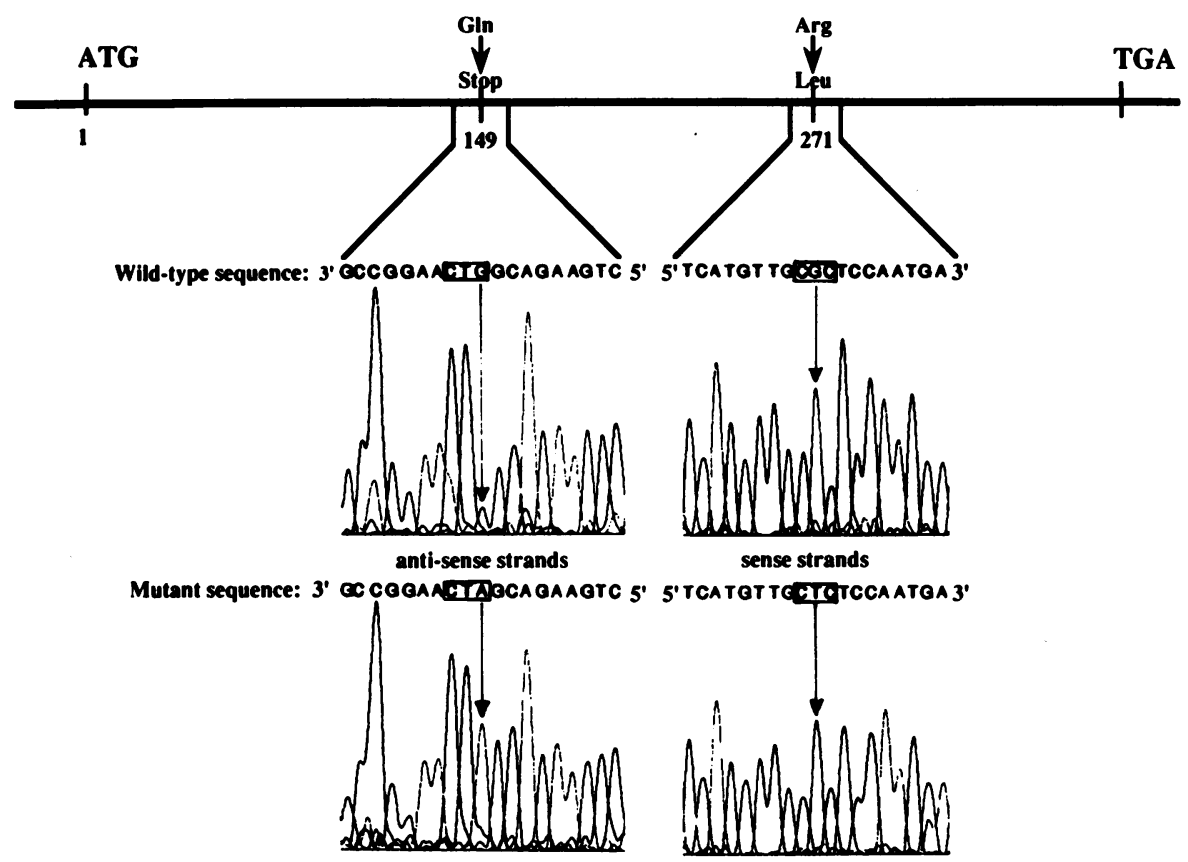

Figure 2. Sequencing data and location of mutations in two patients with HVDRR. One patient was found to have a $\mathrm{C}$ to $\mathrm{T}$ transition in codon 149 in the hinge region, changing it from CAG (glutamine) to TAG (termination codon). Shown is the actual sequence of the antisense strand from this patient with the involved codon boxed. The other patient had a substitution of a $\mathbf{G}$ for a $T$ in codon 271 in the steroid binding domain, resulting in a missense mutation of CGC to CTC and an exchange of arginine for leucine. Shown is the actual sequence of the sense strand for this patient with the corresponding codons boxed.
Transcriptional activation by cotransfection in $C V-1$ cells. The ability of the mutant receptors to activate transcription was evaluated in receptor-deficient CV-1 cells cotransfected with VDR expression plasmid (patient or wild type) and human osteocalcin reporter plasmid. There was strong induction of CAT activity by $1 \mathrm{nM} 1,25(\mathrm{OH})_{2} \mathrm{D}_{3}$ in CV-1 cells transfected with the wild-type VDR construct but no significant induction in those transfected with receptor cDNA from the patients (Fig. 3). A titration with $1,25(\mathrm{OH})_{2} \mathrm{D}_{3}$ concentration varying from $0.01 \mathrm{nM}$ to $1 \mu \mathrm{M}$ showed that CAT activity could be induced at $\sim 50 \mathrm{nM}$ hormone in the cells transfected with the missense mutated (R271L) VDR, reaching maximum induction at $1 \mu \mathrm{M} 1,25(\mathrm{OH})_{2} \mathrm{D}_{3}$, i.e., the same as the maximum

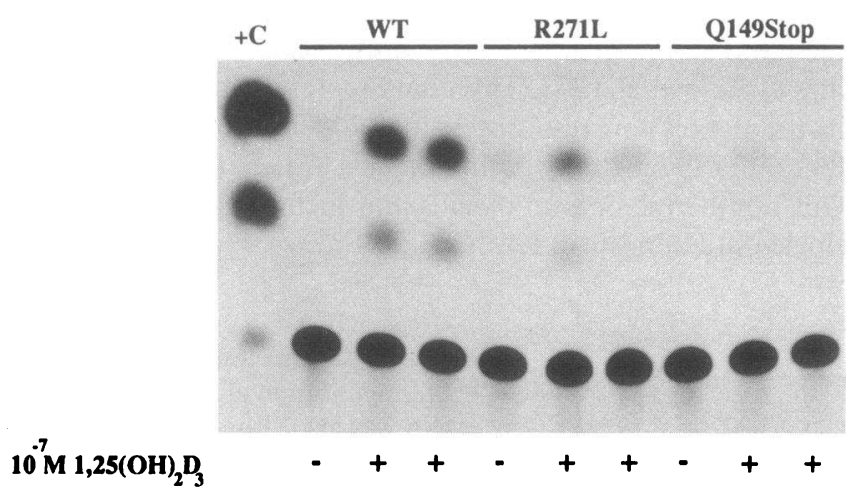

Figure 3. Comparing the transcriptional activation of the osteocalcin promotor by wild-type VDR and the two mutant VDR in the absence and presence of $1,25(\mathrm{OH})_{2} \mathrm{D}_{3}\left(10^{-7} \mathrm{M}\right)$. Wild-type VDR and mutant VDR expression vector constructs were transfected into $\mathrm{CV}-1$ cells along with a human osteocalcin plasmid. Cellular extracts prepared $72 \mathrm{~h}$ later were examined for CAT activity. Each lane represents a separate transfection. Cells in the first lane of each set received ethanol only, while cells in the other lanes received $100 \mathrm{nM}$ $1,25(\mathrm{OH})_{2} \mathrm{D}_{3}$ in ethanol. Mutant VDRs show insignificant transcriptional activation of the osteocalcin promotor compared with the wild-type VDR when stimulated with $1,25(\mathrm{OH})_{2} \mathrm{D}_{3}$. for the wild-type protein (Fig. 4). Consequently, mutation R271L decreases the affinity of the VDR for the ligand by $\sim$ 1,000-fold.

\section{Discussion}

It is now well established that HVDRR is caused by mutations in the VDR $(25,35,36)$. With increasing knowledge about the structure-function relationship of the different members in the

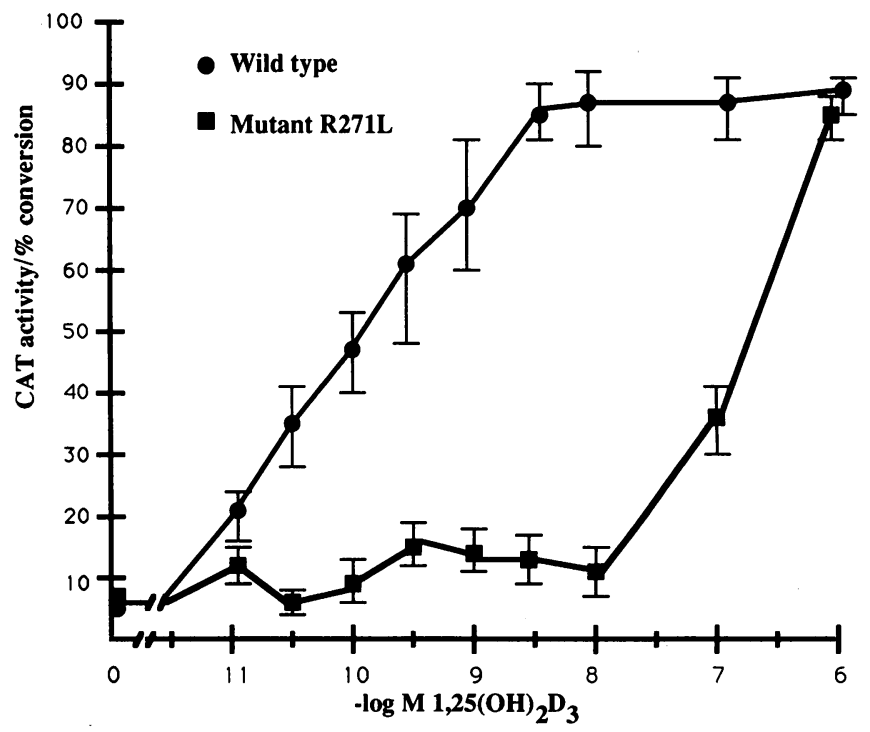

Figure 4. Effect of increasing concentrations of $1,25(\mathrm{OH})_{2} \mathrm{D}_{3}$ on transcriptional activation by wild-type and missense mutated (R271L) VDR. CV-1 cells were transfected with wild-type VDR expression plasmid or the R271L mutant VDR expression plasmid ( 5 $\mu \mathrm{g}$ each ) along with the osteocalcin reporter plasmid ( $1 \mu \mathrm{g})$. Cells were treated with ethanol only or ethanol containing the $1,25(\mathrm{OH})_{2} \mathrm{D}_{3}$ needed to give the concentrations indicated. Each point represents the average of three transfections. 
steroid/thyroid/retinoid receptor superfamily, it is now possible to be more specific about the effects of various mutations. This is especially true for the DNA binding domain of the receptors but increasing evidence is also accumulating regarding the function of subdomains and individual amino acids in the hormone binding domain $(9,13,17,25)$. Deletion construct analysis has suggested that the critical point for $\mathrm{NH}_{2}$-terminal deletions still giving high affinity wild-type binding of $1,25(\mathrm{OH})_{2} \mathrm{D}_{3}$ lies between residues 114 and $166(9)$. Our mutation at codon 149 narrows this further by the fact that there is no detectable cytosolic binding of $1,25(\mathrm{OH})_{2} \mathrm{D}_{3}(27,28)$. The $\mathrm{COOH}$-terminal portion of the glucocorticoid receptor (37, $38)$, androgen receptor $(18,22)$, progesterone receptor (39), estrogen receptor $(40,41)$, and the VDR (9) have been shown to have a repressive effect on transcriptional activation in the absence of ligands. A VDR deletion mutant missing the carboxyl portion from residue 190 to the $3^{\prime}$ terminus has been shown to exhibit considerable constitutive transcriptional activity (9). Similar data exist for the glucocorticoid receptor and the androgen receptor $(18,22,37,38)$. This has been interpreted as evidence for transcriptional domains being present in the amino-terminal portion of the hormone binding domains. This region of the VDR is rich in acidic residues (42) that have been implicated as being important in gene activation within yeast transcription factors (43) and steroid receptors (44). In the mammalian cotransfection analyses reported here, no transcriptional activation by the cDNA Q149X mutant was detected. This could be explained by deletion of these transcriptional activation domains. Additionally, a premature stop mutation at codon 149 not only deletes the entire portion of the molecule that is postulated to form the actual binding pocket for $1,25(\mathrm{OH})_{2} \mathrm{D}_{3}$, but it also deletes a dimerization domain that is essential for receptor binding to the VDR hormone response element. This domain (VDR residues 241-263; Fig. 5) is highly conserved between all the members of the superfamily and is involved in interaction with nuclear proteins $(13,15$, $23)$, possibly RXRbeta $(14,16)$. Point mutations within this domain do not interfere with ligand binding but affect the ability of the receptors to form heterodimers, bind with their response elements, and initiate transcription $(13,15,23)$. The

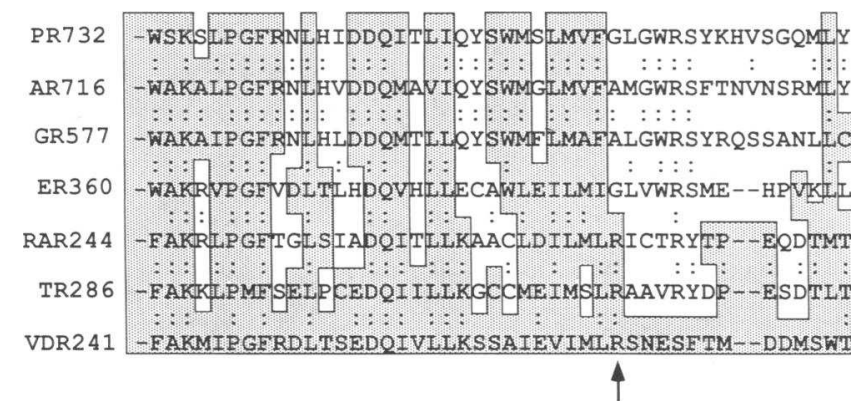

Figure 5. Conservation within a 49 amino acid sequence in the ligand binding domain of the steroid/thyroid/retinoid receptor superfamily. Shown is the sequence of the human VDR along with the homologous regions of the thyroid receptor $(T R)$, retinoic acid receptor $(R A R)$, estrogen receptor $(E R)$, glucocorticoid receptor $(G R)$, androgen receptor $(A R)$, and progesterone receptor $(P R)$. Numbers refer to the position of the first residue on the left for each receptor. Two dots indicate identical amino acid residues. Boxed and shaded areas show the residues conserved in VDR. Our mutation at position $271(\mathrm{R} 271 \mathrm{~L})$ is indicated by the arrow. one previously described stop mutation at amino acid codon 789 (25) is located 3-prime to all of the above-mentioned domains. It has the same effects, with total tissue insensitivity to $1,25(\mathrm{OH})_{2} \mathrm{D}_{3}$ and no specific $1,25-\left[{ }^{3} \mathrm{H}\right](\mathrm{OH})_{2} \mathrm{D}_{3}$ binding. This suggests that the different domains form one functional unit and the ligand binding pocket is constructed by long stretches of three-dimensionally folded polypeptide. The $\mathrm{R} 271 \mathrm{~L}$ mutation is adjacent to the presumed dimerization domain which by homology with the other receptors can be extended up to Arg 271 (Fig. 5). This residue is conserved among the VDR, thyroid receptor, and retinoic acid receptor, and it is possible that it provides an important ligand contact or represents a polar residue critical for the three-dimensional structure of this domain. Our data do not clarify the role of Arg 271 in this regard, but the importance of this residue is emphasized by the recent observation that a mutation at this position (A746D) in the androgen receptor results in androgen insensitivity syndrome (26).

We have described two novel mutations in the hormone binding domain of the VDR that give further insight to the structure-function relationship of this part of the protein. There is increasing evidence that binding of $1,25(\mathrm{OH})_{2} \mathrm{D}_{3}$ to the VDR modifies protein-protein interaction and transcriptional activation through modification of the receptor's structure. The full understanding of the structure-function relationship of the hormone binding domains of the steroid/thyroid/ retinoid receptors awaits the determination of their three-dimensional structure by $\mathrm{x}$-ray crystallography.

\section{Acknowledgments}

DNA sequence analysis was carried out by the Nucleic Acids Core in the Institute for Molecular Genetics at Baylor College of Medicine.

This work was supported by grant NIDDK 41427 from the National Institutes of Health to Mark Hughes, and by the Medical Research Council (UK) to J. L. H. O'Riordan.

\section{References}

1. Haussler, M. R., and A. W. Norman. 1969. Chromosomal receptor for a vitamin D metabolite. Proc. Natl. Acad. Sci. USA. 62:155-162.

2. Brumbaugh, P. F., and M. R. Haussler. 1975. Specific binding of 1 alpha,25-dihydroxycholecalciferol to nuclear components of chick intestine. $J$. Biol. Chem. 250:1588-1594.

3. Haussler, M. R., and T. A. McCain. 1977. Basic and clinical concepts related to vitamin D metabolism and action. N. Engl. J. Med. 297:974-983, 1041-1050.

4. Evans, R. M. 1988. The steroid and thyroid hormone receptor superfamily. Science (Wash. DC). 240:889-895.

5. Beato, M. 1989. Gene regulation by steroid hormones. Cell. 56:335-344. 6. McDonnell, D. P., D. J. Mangelsdorf, J. W. Pike, M. R. Haussler, and B. W. OMalley. 1987. Molecular cloning of complementary DNA encoding the avian receptor for vitamin D. Science (Wash. DC). 235:1214-1217.

7. Baker, A. R., D. P. McDonnell, M. R. Hughes, T. M. Crisp, D. J. Mangelsdorf, M. R. Haussler, J. W. Pike, J. Shine, and B. W. OMalley. 1988. Cloning and expression of full-length cDNA encoding human vitamin D receptor. Proc. Natl. Acad. Sci. USA. 85:3294-3298.

8. Burmester, J. K., R. J. Wiese, N. Maeda, and H. F. DeLuca. 1988. Structure and regulation of the rat 1,25-dihydroxyvitamin D3 receptor. Proc. Natl. Acad. Sci. USA. 85:9499-9502.

9. McDonnell, D. P., R. A. Scott, S. A. Kerner, B. W. OMalley, and J. W. Pike. 1989. Functional domains of the human vitamin D3 receptor regulate ostercalcin gene expression. Mol. Endocrinol. 3:635-644.

10. Freedman, L. P., B. F. Luisi, Z. R. Korszun, R. Basavappa, P. B. Sigler, and K. R. Yamamoto. 1988. The function and structure of the metal coordination sites within the glucocorticoid receptor DNA binding domain. Nature (Lond.). 334:543-546.

11. Luisi, B. F., W. X. Yu, Z. Otwinowski, L. P. Freedman, K. R. Yamamoto, and P. B. Sigler. 1991. Crystallographic analysis of the interaction of the glucocorticoid receptor with DNA. Nature (Lond.). 352:497-505. 
12. Rut, A. R., M. Hewison, K. Kristjansson, B. F. Luisi, R. E. Walker, J. L. H. O'Riordan, and M. R. Hughes. 1992. Mutations in the vitamin D receptor gene and their stereochemical consequences. J. Bone Miner. Res. 7:S108. (Abstr.)

13. Hsieh, J. C., S. Nakajima, P. N. McDonald, A. Haussler, M. R. Haussler, and G. K. Whitfield. 1992. A highly conserved region in the hormone binding domain of the human vitamin D receptor contains residues vital for transcriptional activation. J. Bone Miner. Res. 7:S109. (Abstr.)

14. Yu, V. C., C. Delsert, B. Anderson, J. M. Holloway, O. V. Devary, A. M. Naar, S. Y. Kim, J.-M. Boutin, C. K. Glass, and M. G. Rosenfeld. 1991. RXRß: a coregulator that enhances binding of retinoic acid, thyroid hormone, and vitamin D receptors to their cognate response elements. Cell. 67:1251-1266.

15. O'Donnell, A. L., E. D. Rosen, D. S. Darling, and R. J. Koenig. 1991. Thyroid hormone receptor mutations that interfere with transcriptional activation also interfere with receptor interaction with a nuclear protein. Mol. Endocrinol. 5:94-99.

16. Leid, M., P. Kastner, R. Lyons, H. Nakshatri, M. Saunders, T. Zacharewski, J.-Y. Chen, A. Staub, J.-M. Garnier, S. Mader, and P. Chambon. 1992. Purification, cloning, and RXR identity of the HeLa cell factor with which RAR or TR heterodimerizes to bind target sequences efficiently. Cell. 68:377-395.

17. Nakajima, S., J. C. Hsieh, G. K. Whitfield, P. N. MacDonald, M. A. Galligan, C. A. Haussler, and M. R. Haussler. 1992. The C-terminal region of the human vitamin $D$ receptor is essential to form a complex with a receptor auxiliary factor required for high affinity binding to the vitamin D responsive element. $J$. Bone Miner. Res. 7:S147. (Abstr.)

18. Simental, J. A., M. Sar, M. V. Lane, F. S. French, and E. M. Wilson. 1991. Transcriptional activation and nuclear targeting signals of the human androgen receptor. J. Biol. Chem. 226:510-518.

19. Miesfield, R., P. J. Godowski, B. A. Maler, and K. R. Yamamoto. 1987. Glucocorticoid receptor mutants that define small regions sufficient for enhanced activation. Science (Wash. DC). 236:423-427.

20. Tora, L., J. White, L. Brou, D. Tasset, N. Webster, E. Sheer, and P. Chambon. 1989. The human estrogen receptor has two independent non-acidic transcriptional activation functions. Cell. 59:477-487.

21. Dobson, A. D., O. M. Conneely, W. Beattie, B. L. Maxwell, P. Mak, M. J. Tsai, W. T. Schrader, and B. W. OMalley. 1989. Mutational analysis of the chicken progesterone receptor. J. Biol. Chem. 264:4207-4211.

22. Jenster, G., H. A. G. M. van der Korput, C. van Vroonhoven, T. H. van der Kwast, J. Trapman, and A. O. Brinkmann. 1991. Domains of the human androgen receptor involved in steroid binding, transcriptional activation and subcellular localization. Mol. Endocrinol. 5:1396-1404.

23. O'Donnell, A. L., and R. J. Koenig. 1990. Mutational analysis identifies a new functional domain of the thyroid hormone receptor. Mol. Endocrinol. 4:715-720.

24. Malloy, P. J., Z. Hochberg, D. Tiosano, J. W. Pike, M. R. Hughes, and D. Feldman. 1990. The molecular basis of hereditary 1,25-dihydroxyvitamin $D_{3}$ resistant rickets in seven related families. J. Clin. Invest. 86:2071-2079.

25. Ritchie, H. H., M. R. Hughes, E. T. Thompson, P. Malloy, Z. Hochberg, D. Feldman, J. W. Pike, and B. W. O'Malley. 1989. An ochre mutation in the vitamin D receptor gene causes hereditary 1,25-dihydroxyvitamin D3-resistant rickets in three families. Proc. Natl. Acad. Sci. USA. 86:9783-9787.

26. McPhaul, M. J., M. Marcelli, S. Zoppi, C. M. Wilson, J. E. Griffin, and J. D. Wilson. 1992. Mutations in the ligand-binding domain of the androgen receptor gene cluster in two regions of the gene. J. Clin. Invest. 90:2097-2101.

27. Kruse, K., E. Feldmann, and H. Bartels. 1988. Hypoparathyroidism in hereditary resistance to $1,25(\mathrm{OH}) 2 \mathrm{D}$ during long term treatment with excessive doses of vitamin D3. In Proceedings of the Seventh Workshop on Vitamin D. A. W. Norman, R. Bouillon, and M. Thomasset, editors. Walter de Gruyter \& Co., New York. 958 pp.
28. Fraher, L. J., G. N. Hendy, H. Yani, L. Nicholson, D. Grant, and J. L. H. O'Riordan. 1986. Interactions of 1,25-dihydroxyvitamin D3 with cultured skin fibroblasts: reduced metabolism of 1,25 dihydroxyvitamin D3 in a patient with vitamin D dependent rickets type II. Eur. J. Pediatr. 145:389-395.

29. Hewison, M., S. Barker, A. Brennan, J. Nathan, D. R. Katz, and J. L. H. O'Riordan. 1989. Autocrine regulation of 1,25-dihydroxycholecalciferol metabolism in myelomonocytic cells. Immunology. 68:247-252.

30. Saiki, R. K., S. Scharf, F. Faloona, K. B. Mullis, G. T. Horn, H. A. Erlich, and N. Arnheim. 1985. Enzymatic amplification of beta-globin genomic sequences and restriction site analysis for diagnosis of sickle cell anemia. Science (Wash. DC). 230:1350-1354.

31. Mongkolsuk, S. 1988. Novel eukaryotic expression vectors which permit single stranded replication in Escherichia coli and in vitro translational analyses of cloned genes. Gene (Amst.). 70:313-319.

32. Morrison, N. A., J. Shine, J.-C. Fragonas, V. Verkest, L. McMenemy, and J. A. Eisman. 1989. 1,25 dihydroxyvitamin D-responsive element and glucocorticoid repression in the osteocalcin gene. Science (Wash. DC). 246:1158-1161.

33. Gorman, C. M., L. F. Moffat, and B. H. Howard. 1982. Recombinant genomes which express chloramphenicol acetyltransferase in mammalian cells. Mol. Cell. Biol. 2:1044-1051.

34. Colston, K., and D. Feldman. 1982. 1,25 dihydroxyvitamin D3 receptors and functions in cultured pig kidney cells (LL CPK): regulation of 24,25-dihydroxyvitamin D3 production. J. Biol. Chem. 257:2504-2508.

35. Saijo, T., M. Ito, E. Takeda, A. H. M. Mahbubul Huq, E. Naito, I. Yokota T. Sone, J. W. Pike, and Y. Kuroda. 1991. A unique mutation in the vitamin D receptor gene in three Japanese patients with vitamin D-dependent rickets type II: utility of single-strand conformation polymorphism analysis for heterozygous carrier detection. Am. J. Hum. Genet. 49:668-673.

36. Hughes, M. R., P. J. Malloy, D. G. Kieback, R. A. Kesterson, J. W. Pike, D. Feldman, and B. W. OMalley. 1988. Point mutations in the human vitamin D receptor gene associated with hypocalcemic rickets. Science (Wash. DC). 242:1702-1705.

37. Oro, A. E., S. M. Hollenberg, and R. M. Evans. 1988. Transcriptional inhibition by a glucocorticoid receptor-beta-galactosidase fusion protein. Cell. 55:1109-1114.

38. Picard, D., S. J. Salser, and K. R. Yamamoto. 1988. A movable and regulable inactivation function within the steroid binding domain of the glucocorticoid receptor. Cell. 54:1073-1080.

39. Gronemeyer, H., B. Turcotte, C. Quirin Stricker, M. T. Bocquel, M. E. Meyer, Z. Krozowski, J. M. Jeltsch, T. Lerouge, J. M. Garnier, and P. Chambon. 1987. The chicken progesterone receptor: sequence, expression and functional analysis. EMBO (Eur. Mol. Biol. Organ.). J. 6:3985-3994.

40. Kumar, V., S. Green, G. Stack, M. Berry, J. R. Jin, and P. Chambon. 1987. Functional domains of the human estrogen receptor. Cell. 51:941-951.

41. Bocquel, M. T., V. Kumar, C. Stricker, P. Chambon, and H. Gronemeyer. 1989. The contribution of the $\mathrm{N}$ - and $\mathrm{C}$-terminal regions of steroid receptors to activation of transcription is both receptor and cell specific. Nucleic Acids Res. 17:2581-2595.

42. Haussler, M. R., D. J. Mangelsdorf, B. S. Komm, C. M. Terpening, K. Yamaoka, E. A. Allegretto, A. R. Baker, J. Shine, D. P. McDonnell, M. R. Hughes, N. L. Weigel, B. W. O'Malley, and J. W. Pike. 1988. Molecular biology of the vitamin D hormone. Recent Prog. Horm. Res. 44:263-305.

43. Hope, I. A., S. Mahadevan, and K. Struhl. 1988. Structural and functional characterization of the short acidic transcriptional activation region of yeast GCN4 protein. Nature (Lond.). 333:635-640.

44. Webster, N., J. R. Jin, S. Green, M. Hollis, and P. Chambon. 1988. The yeast UASG is a transcriptional enhancer in human HeLa cells in the presence of the GAL4 trans-activator. Cell. 52:169-178. 